\title{
Adipose tissue-derived mesenchymal stem cells reduce endometriosis cellular proliferation through their anti-inflammatory effects
}

\author{
Fatma Y. Meligy 1,2 , Dalia A. Elgamal ${ }^{1,2}$, Lobna A. Abdelzaher ${ }^{2,3}$, Maha Y. Khashbah'², Mohamed A. El-Mokhtar ${ }^{2,4}$, \\ Ayat A. Sayed ${ }^{2,5}$, Abeer M. Refaiy, ${ }^{2,6}$, Essam R. Othman ${ }^{2,7}$ \\ ${ }^{1}$ Department of Histology and Cell Biology, Faculty of Medicine, ${ }^{2}$ Reproductive Science Research Center, Departments of ${ }^{3}$ Pharmacology, ${ }^{4}$ Microbiology \\ and Immunology, ${ }^{5}$ Biochemistry, ${ }^{6}$ Pathology, and ${ }^{7}$ Obstetrics and Gynecology, Faculty of Medicine, Assiut University, Assiut, Egypt
}

Objective: Endometriosis is a chronic debilitating inflammatory condition characterized by the presence of endometrial tissues outside the uterine cavity. Pelvic soreness and infertility are the usual association. Due to the poor effectiveness of the hormone therapy and the high incidence of recurrence following surgical excision, there is no single effective option for management of endometriosis. Mesenchymal stem cells (MSCs) are multipotent stromal cells studied for their broad immunoregulatory and anti-inflammatory properties; however, their efficiency in endometriosis cases is still a controversial issue. Our study aim was to evaluate whether adipose tissue-derived MSCs (AD-MSCs) could help with endometriosis through their studied anti-inflammatory role.

Methods: Female Wistar rats weighting 180 to $250 \mathrm{~g}$ were randomly divided into two groups: group 1, endometriosis group; established by transplanting autologous uterine tissue into rats' peritoneal cavities and group 2, stem cell treated group; treated with AD-MSCs on the 5th day after induction of endometriosis. The proliferative activity of the endometriosis lesions was evaluated through Ki67 staining. Quantitative estimation of interferon $\gamma$, tumor necrosis factor- $a$, interleukin (IL)-6, IL-1 13 , IL-10, and transforming growth factor $\beta$ expression, as well as immunohistochemical detection of CD68 positive macrophages, were used to assess the inflammatory status.

Results: The size and proliferative activity of endometriosis lesions were significantly reduced in the stem cell treated group. Stem cells efficiently mitigated endometriosis associated chronic inflammatory reactions estimated through reduction of CD68 positive macrophages and the expression of the proinflammatory cytokines.

Conclusion: Stem cell therapy can be considered a novel remedy in endometriosis possibly through its anti-inflammatory and antiproliferative properties.

Keywords: CD68; Cytokines; Endometriosis; Ki67; Mesenchymal stem cells; Rats

Received: December 31, 2020 · Revised: June 21, 2021 · Accepted: June 23, 2021 Corresponding author: Essam R. Othman

Department of Obstetrics and Gynecology, Faculty of Medicine, Assiut University, Assiut 71515, Egypt

Tel:+20-10-0660-7801 E-mail: essamothman@aun.edu.eg

Co-corresponding author: Lobna A. Abdelzaher

Department of Pharmacology, Faculty of Medicine, Assiut University, Assiut 71515, Egypt

Tel: +20-10-0660-7801 E-mail: Lobna@aun.edu.eg

*This research was supported by funding of Assiut Medical School Grants Office, Faculty of Medicine, Assiut University.

This is an Open Access article distributed under the terms of the Creative Commons Attribution Non-Commercial License (http://creativecommons.org/licenses/by-nc/4.0/) which permits unrestricted non-commercial use, distribution, and reproduction in any medium, provided the original work is properly cited.

\section{Introduction}

Endometriosis is a chronic inflammatory gynecological condition characterized by the presence of ectopic glands and/or endometrial stroma outside the uterine cavity, which may be superficial peritoneal, vaginal, or deep endometriosis $[1,2]$. It is a benign pathology [3] detected in $20 \%-50 \%$ of women investigated for infertility probably due to the associated adhesions, fibrosis, endocrine abnormalities and immunological disturbances [4]. Dysmenorrhea, dyspareunia and chronic pelvic pain are the usual complaints $[5,6]$. Endometriosis is considered the major cause of hysterectomy and hospitalization in USA imposing huge economic burden on healthcare system [7]. 
Chronic intraperitoneal inflammation is a distinct feature of endometriosis [8-10]. $T$ helper and regulatory $T$ (Treg) cell subsets are recruited and activated by endometriosis implants, resulting in an acute inflammatory response [11]. Monocytes/macrophages sustain a state of chronic inflammation [12-18] after acute inflammation has subsided, promoting the development and survival of endometriosis lesions [19-21].

The current endometriosis treatment options are limited to suppressing ovarian function simulating premature menopause or surgical removal of the lesions [22]. Hormonal therapy, androgen and gonadotropin-releasing hormone, beside non-steroidal anti-inflammatory medications are currently used to treat pain [23]. Hormonal treatment has little to no benefit, with a high rate of endometriosis recurrence [23] and undesirable adverse effects such as hot flushes and genital atrophy [24]. It should only, therefore, be used in conjunction with assisted reproductive technology [11]. Multiple operations may be inevitable [24] to kill or remove the majority of endometriosis implants or restore normal pelvic anatomy [11], however, their role is still controversial. As a result, a novel therapeutic approach for effective management of endometriosis is mandatory.

Mesenchymal stem cells (MSCs) are non-immunogenic cells that can differentiate into a variety of tissue types $[25,26]$. In inflammatory conditions, they release immunomodulatory, angiogenic, and antiapoptotic factors [25-27]. Their role in cases of endometriosis is still a point of argument [28].

In this context, endometriosis was induced in female rats by autotransplantation uterine implants into their peritoneal cavity. Rats are an excellent experimental model due to their similarity in pathology as well as therapeutic response to human endometriosis [29]. They display human-like symptoms such as decreased fertility and fecundity [29].

The current study has been conducted to investigate the possible mitigating impact of adipose tissue-derived MSCs (AD-MSCs) in endometriosis rat model, as well as their effect on their cytokine profile. Our target was achieved through studying the effect MSCs on endometriosis lesions histopathology, proliferative activity, the expression of CD68 positive macrophages and the proinflammatory cytokines.

\section{Methods}

\section{Animals and experimental design}

All procedures were performed in agreement with the ethical principles of Assiut University Animal Care Committee (approval reference No. 17300077) and with the internationally accepted principles for Use and Care of Laboratory Animals. Twenty adult female Wistar albino rats weighting 180 to $250 \mathrm{~g}, 3$ to 6 months of age were purchased from the animal house of Faculty of Medicine, Assiut Uni- versity. They were housed and bred in a standard animal-grade room with four to five rats in each cage at a 12-hour light/dark cycle with free access to food (laboratory chow) and water ad libitum. The animal room is well-ventilated with temperature ranging from $23^{\circ} \mathrm{C}$ to $26^{\circ} \mathrm{C}$. Estrus cycles were synchronized to estrus phase through furnishing female rat cages with beddings from male rat cages 72 hours before the surgery or tissue collection.

\section{Establishment of the rat model of endometriosis}

Surgical induction of endometriosis was achieved through autologous transplantation of one of the female rat's uterine horn onto its intestinal mesentery $[30,31]$. Briefly, rats were anesthetized with ketamine (90 mg/kg) intraperitoneally (i.p.) and xylazine (10 mg/kg) i.p. Skin on the ventral aspect was cleaned with $70 \%$ ethyl alcohol. A lower abdominal midline incision was performed; the left uterine horn was exposed, ligated at cervicouterine junction with silk suture (No. 40) then excised and opened longitudinally. The excised horn was submerged in a sterile small petri dish containing Ham's F-12 medium with $100 \mathrm{U} / \mathrm{mL}$ penicillin and $100 \mathrm{pg} / \mathrm{mL}$ streptomycin, warmed to $37^{\circ} \mathrm{C}$. It was divided into three pieces: each piece was 2 to $3 \mathrm{~mm}$. These cut pieces have been sutured with non-absorbable sutures (Prolene 4/0) onto the intestinal mesentery nearby a branch of the mesenteric arterial arcade. The Abdomen was closed in layers. Animals were observed until full recovery. They were given nalbuphine for postoperative analgesia and were kept on antibiotics for 3 days postoperatively.

\section{Isolation of AD-MSCs}

MSCs were isolated from adipose tissue (60-100 mL) obtained from lipectomy procedures carried out in plastic surgery department in Assiut University. The samples were washed with 5\% antibiotic phosphate buffered saline (PBS) then digested in warm filtered 0.1 collagenase solutions dissolved in PBS in a shaking water bath at $37^{\circ} \mathrm{C}$ for 60 minutes. The suspension was centrifuged and the supernatant floating fatty layer was discarded. The precipitated cell pellets were re-suspended in freshly prepared complete; Dulbecco's modified eagle medium (DMEM) with $10 \%$ FBS and 1\% penicillin streptomycin; filtered through a $100 \mu \mathrm{m}$ nylon cell strainer (Falcon; Corning, NY, USA) and cultured in $75 \mathrm{~cm}^{2}$ culture flasks. The media was changed after the first 48 hours to remove the non-adherent cells, and then changed every $2-3$ days till a confluence of $80 \%-90 \%$ was attained [32].

\section{Differentiation of AD-MSCs}

For the differentiation analysis, AD-MSCs passage 2 that reached nearly $80 \%$ confluency was enzymatically harvested in trypsin-ethylenediaminetetraacetic acid (EDTA 0.25\%; Gibco, Amarillo, TX, USA). 
AD-MSCs were cultured in 24 well-plate $\left(1 \times 10^{4}\right.$ cell/well) in the complete growth medium DMEM low glucose supplemented with $10 \%$ FBS. After reaching $100 \%$ confluence, the medium was replaced with adipogenic induction medium (adipogenic differentiation medium; R\&D Systems, Minneapolis, MN, USA; cat no SC006), a chondrogenic induction medium (chondrogenesis differentiation kit; R\&D Systems; cat no. SC006) and osteogenic induction medium (Osteogenesis Differentiation Kit; R\&D Systems; Cat no SC006). After 7-21 days incubation (for adipogenesis), 14-21 days (for chondrogenesis) and 14-21 days (for osteogenesis), the cells were observed using an inverted microscope. The cells were fixed in $4 \%$ formaldehyde in saline and stained, using oil red $\mathrm{O}$ staining for lipid vacuoles in adipocyte, Alcian Blue staining, which is specific for glycosaminoglycan, one of the components in chondrocytes extracellular matrix and Alizarin Red staining which is specific for mineralized matrix expression in osteocytes. The cell were observed and photographed by inverted microscope.

\section{Immunophenotyping of AD-MSCs using flowcytometry}

AD-MSCs of passage two were trypsinized using 10\% trypsin EDTA solution. Then, they were incubated with CD90, CD44, CD45, and CD34 primary antibodies (Santa Cruz Biotechnology, Dallas, TX, USA) in $1 \%$ bovine serum for 30 minutes. MSCs were washed by PBS, centrifuged for 5 minutes, incubated with the secondary antibody for 30 minutes, washed twice then subjected to fluorescence-activated cell sorting cell analyzer [33].

\section{Transplantation of AD-MSCs}

The $2 \times 10^{6}$ of AD-MSCs were suspended in $500 \mu \mathrm{L}$ PBS and injected i.p. as a single dose in the stem cell treated group.

\section{Animal groups}

Rats were randomly assigned into two groups. Group 1: endometriosis group $(n=10)$; endometriosis was induced through autologous transplantation of one of the female rat's uterine horn onto its intestinal mesentery [30,31]. After induction, rats were kept without any interference for 4 weeks. Group 2: stem cell treated group $(n=10)$; rats were injected with AD-MSCs in a dose of $2 \times 10^{6}$ on the 5 th day after induction of endometriosis. Both groups were scarified 4 weeks after induction of endometriosis.

\section{Histopathological studies}

At the end of the experiment, rats were sacrificed under general anesthesia through inhalation of ethyl ether. Rats from each group were intracardially perfused by $10 \%$ formaldehyde solution. Specimens of ectopic endometriosis lesions from both groups were carefully excised, immersed into 10\% formaldehyde, dehydrated, cleared, and embedded in paraffin. Paraffin sections were serially cut from paraffin blocks (5 $\mu \mathrm{m}$-thick) using a microtome and stained with Hematoxylin and Eosin (H\&E) for examination with light microscope [34].

\section{Immunohistochemistry studies}

Paraffin sections were serially cut from paraffin blocks ( $5 \mu \mathrm{m}$-thick). Antigen retrieval was achieved by boiling the sections with sodium citrate buffer $(0.01 \mathrm{~mol} / \mathrm{L}, \mathrm{pH} 6)$ for 9 minutes. Sections were incubated for 10 minutes in $3 \%$ hydrogen peroxide to block endogenous peroxidase activity. Immunohistochemical staining was performed by the avidin-biotin immunoperoxidase method. Primary antibodies Ki67 rabbit polyclonal antibody (Novus Biologicals, Centennial, CO, USA; catalog no. NB500-170SS) and CD68 mouse monoclonal antibody (Novus Biologicals; catalog no. NBP2-29406) were used in a dilution of 1:50 and 1:100 respectively. Sections were incubated with the primary antibodies overnight at $4^{\circ} \mathrm{C}$. Negative control sections were subjected to the same protocol. Positive control sections for Ki67 were carried out on human breast carcinoma tissue; however rat tonsillar tissue was used for CD68. The UltraVision horseradish peroxidase detection system (Thermo Fisher Scientific, Waltham, MA, USA) was used. The slides were incubated with biotinylated goat antipolyvalent as a secondary antibody at room temperature for 30 minutes then were counterstained with Meyer hematoxylin, dehydrated, and mounted.

\section{Morphometric studies}

Morphometric studies have been performed using the computer-assisted image analysis (Soft Imaging System, Analysis-2004; Olympus, Tokyo, Japan). The number of Ki67 and CD68 positive cells were counted using $\times 100$ oil immersion lens in five non-overlapping fields in six randomly chosen sections from three different rats from each group.

\section{Cytokine expression levels}

Rats' macrophages were obtained from peritoneal and endometriosis tissues. Primary peritoneal rat macrophages were isolated as described previously [35]. Briefly, macrophages were collected from the peritoneal cavity of both endometriosis and stem cell treated group by flushing the peritoneal cavity twice with $50 \mathrm{~mL}$ of ice-cold PBS. The recovered cells were washed two times, counted, and resuspended in $1 \mathrm{~mL}$ TRIZOL reagent (Invitrogen, Waltham, MA, USA). Ectopic endometriosis tissues from both groups were collected and resuspended in $1 \mathrm{~mL}$ TRIZOL reagent and RNA was extracted from the samples according to the manufacturer protocol. The reverse transcription was carried out using the high-capacity CDNA reverse transcription kit (Thermo Fisher scientific). Quantitative estimation of interferon $\gamma$ (IFN $\gamma$ ), tumor necrosis factor- $a$ (TNF-a), interleukin (IL)-6, 
IL-1 $\beta$, IL-10, transforming growth factor $\beta$ (TGF- $\beta$ ) and glyceraldehyde 3-phosphate dehydrogenase (GAPDH) was carried out using power SYBR green PCR master mix (Applied Biosystems, Waltham, $M A, U S A)$. Primers used for the real-time-polymerase chain reaction $(P C R)$ reactions are shown in Table 1. PCR reactions were carried out using the Applied Biosystems 7500 instrument including an initial denaturation step at $94{ }^{\circ} \mathrm{C}$ for 10 minutes followed by a 43-step cycling procedure (denaturation at $94^{\circ} \mathrm{C}$ for 30 seconds, annealing at $60^{\circ} \mathrm{C}$ for 30 seconds, and extension at $72^{\circ} \mathrm{C}$ for 30 seconds). Cytokine

Table 1. Oligonucleotide primers used for the RT-PCR reactions

\begin{tabular}{|c|c|}
\hline Target gene & Sequence \\
\hline \multirow[t]{2}{*}{$I F N \gamma$} & 5'- GAGGAACTGGCAAAAGGACG -3' \\
\hline & 5'-TCAGGTGCGATTCGATGACA -3' \\
\hline \multirow[t]{2}{*}{$T N F-a$} & 5'-ATGGGCTCCCTCTCATCAGT -3' \\
\hline & 5'-GCTTGGTGGTTTGCTACGAC -3' \\
\hline \multirow[t]{2}{*}{ IL6 } & 5'-CTTGGAAATGAGAAAAGAGTTGTGC -3' \\
\hline & 5'- ACGGAACTCCAGAAGACCAG -3' \\
\hline \multirow[t]{2}{*}{$I L 1 \beta$} & 5'-GCAGCTTTCGACAGTGAGGAG- 3' \\
\hline & 5'-GCTTCTCCACAGCCACAATG -3' \\
\hline \multirow[t]{2}{*}{ IL10 } & 5'-CGACGCTGTCATCGATTTCTC - 3' \\
\hline & 5'-CAGTAGATGCCGGGTGGTTC -3' \\
\hline \multirow[t]{2}{*}{ TGF $\beta$} & 5'- GACCGCAACAACGCAATCTA -3' \\
\hline & 5'-CGTGTTGCTCCACAGTTGAC -3' \\
\hline \multirow[t]{2}{*}{ GAPDH } & 5'- CAGGGCTGCCTTCTCTTGTG -3' \\
\hline & 5'- GATCTCGCTCCTGGAAGATGG -3' \\
\hline
\end{tabular}

RT-PCR, real-time reverse transcription-polymerase chain reaction.
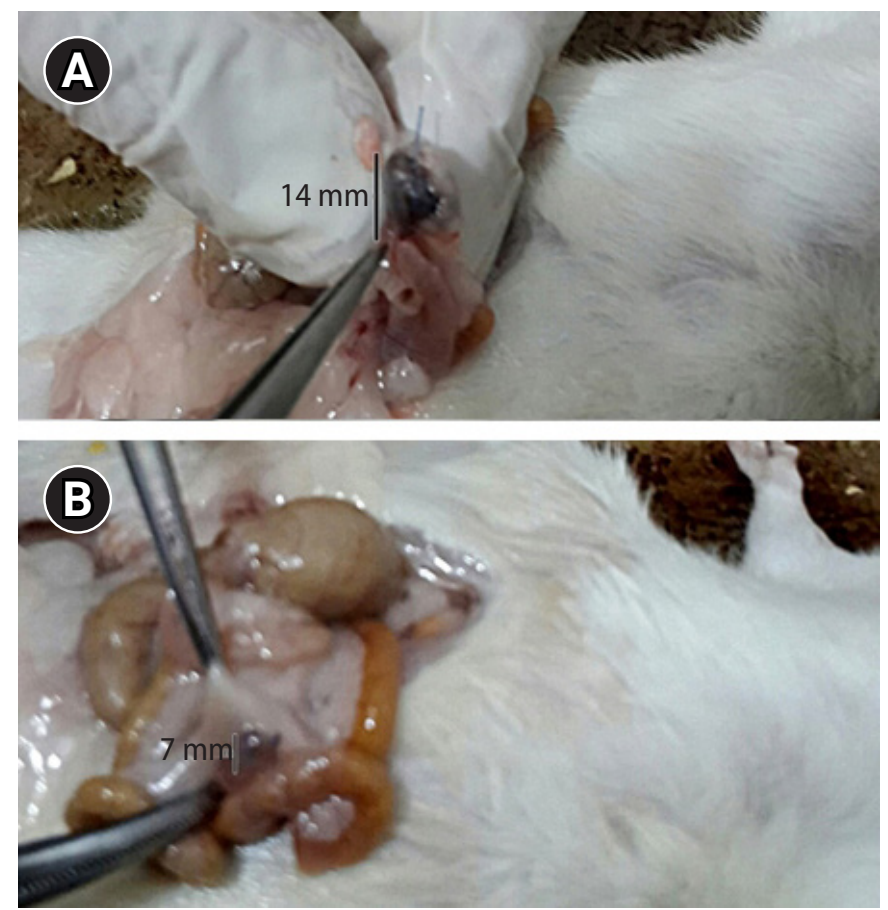

expression levels were normalized to the level of GAPDH as an endogenous control and quantified by the $2^{-\Delta \Delta C T}$ method.

\section{Statistical analysis}

Data were expressed as mean \pm standard error of the mean. Unpaired $t$-test was used for comparing between the treated and non-treated groups. The difference among groups was considered significant for $p<0.05$. Statistical tests were carried out using IBM SPSS ver. 25.0 (IBM Corp., Armonk, NY, USA).

\section{Results}

\section{Macroscopic observation of the endometriosis lesions}

The endometriosis lesions, identified by the non-absorbable Prolene suture, were examined in both study groups. Endometriosis group showed implants of ectopic endometrium within the intestinal mesentery detected as hemorrhagic cystic bulge full of fluid and surrounded by adhesions (Figure 1A). Endometriosis colony size was apparently smaller in the stem cell treated group compared to the endometriosis group (Figure 1B), which was documented by statistical analysis (Figure 1C).

\section{Microscopic morphology of isolated AD-MSCs}

After culturing for 7 days, the isolated MSCs appeared elongated spindle shaped with long cytoplasmic processes and clear elliptical nuclei (Figure 2A).

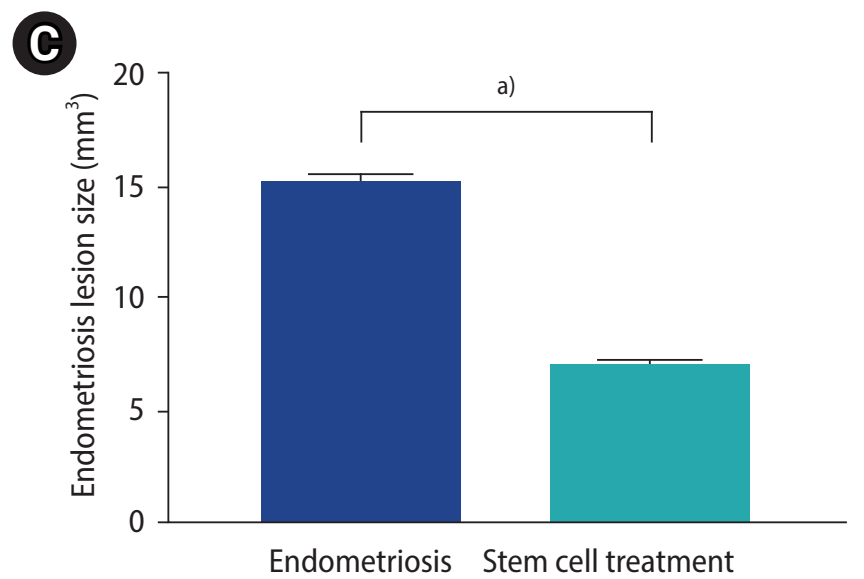

Figure 1. Macroscopic observations of the endometriosis lesions of the study groups. (A) Endometriosis group showing fluid-filled endometriosis lesion at the intestinal mesentery. (B) Stem cell treated group showing smaller endometriosis lesion compared to the endometriosis group. (C) Endometriosis lesion size. Values are presented as mean \pm standard error of the mean . ${ }^{\text {a) }} p<0.001$. 

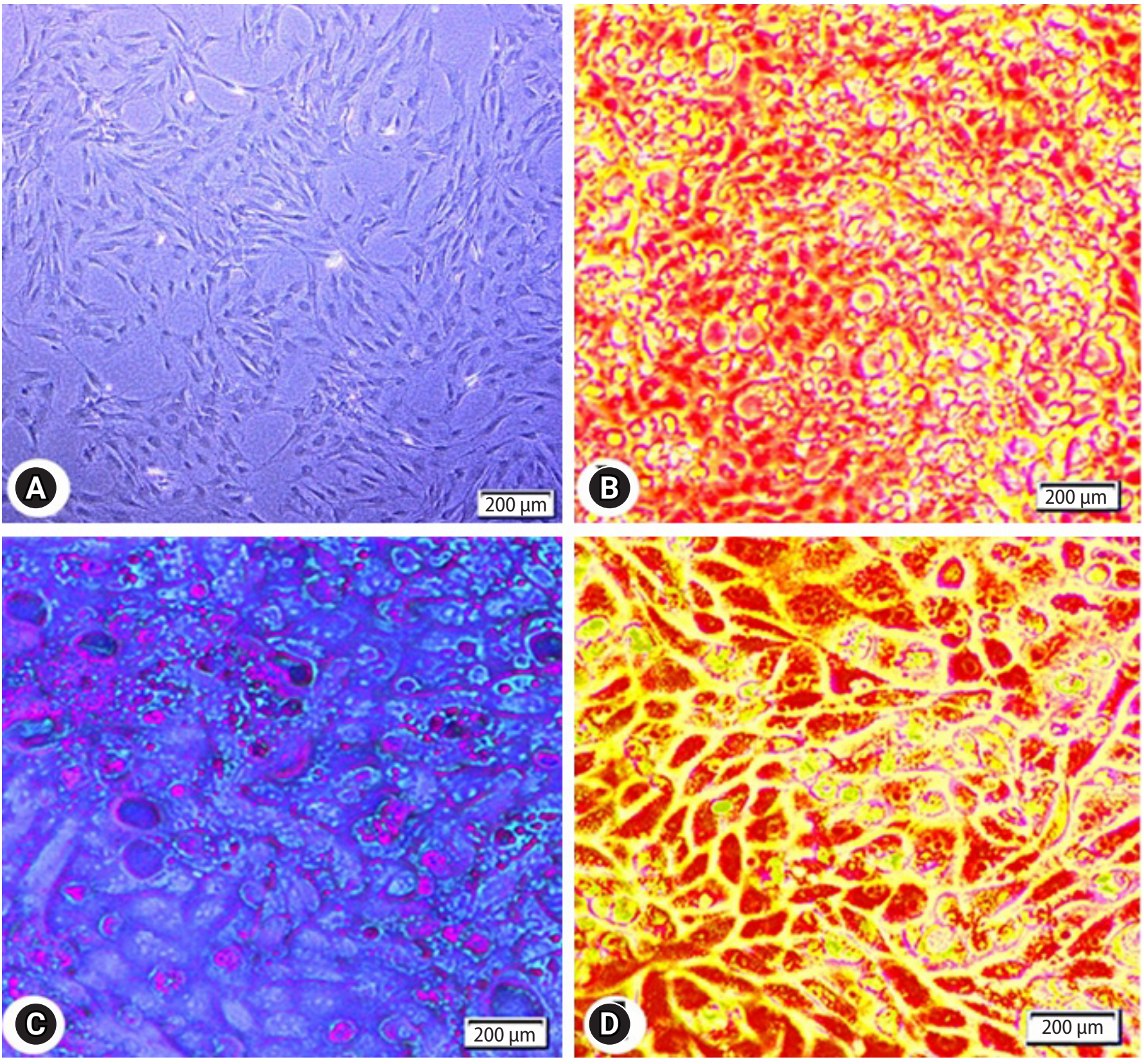

Figure 2. Photomicrographs of adipose tissue-derived mesenchymal stem cells (AD-MSCs). (A) Isolated AD-MSCs after 7 days culture showing $80 \%$ confluent. The cells are fibroblast-like shape with fusiform nucleus and tapering ends. (B) AD-MSCs differentiated into adipocytes and stained with Red Oil O. (C) AD-MSCs differentiated into chondrocytes and stained with Alcian blue. (D) AD-MSCs differentiated into osteocytes and stained with Alizarin red.

\section{Differentiation of AD-MSCs}

The lipid vacuoles were visible in AD-MSCs that had differentiated into adipocytes and were stained with red oil (Figure 2B). Glycosaminoglycans were visible in AD-MSCs which had discriminated into chondrocytes and were stained with Alcian blue (Figure 2C). Calcium deposits were visible in AD-MSCs that had separated into osteocytes and were stained with Alizarin red (Figure 2D).

\section{Flowcytometric analysis of AD-MSCs}

Expression of MSCs surface markers was evaluated through flowcytometric analysis. CD44 and CD90 markers were highly expressed in AD-MSCs, while CD45 and CD34 markers were weakly expressed (Figure 3).

\section{Histopathological results}

H\&E stained sections from the endometriosis group showed foci 
of multiple endometrial glands and stroma surrounded by mononuclear inflammatory cells (Figure 4A). In sections from stem cells treated group reveled few endometrial glands surrounded by stromal cells (Figure 4B), which was shown in statistical data (Figure 4C). Many hemosiderin-laden macrophages were observed in sections from endometriosis group (Figure 4D) while in stem cells treated group, few macrophages laden with hemosiderin were observed (Figure 4E). Number of hemosiderin-laden macrophages was significantly decreased in the stem cell treated group compared to the endometriosis group (Figure 4F).

\section{Immunohistochemistry studies}

In the endometriosis group, immunohistochemical staining re-
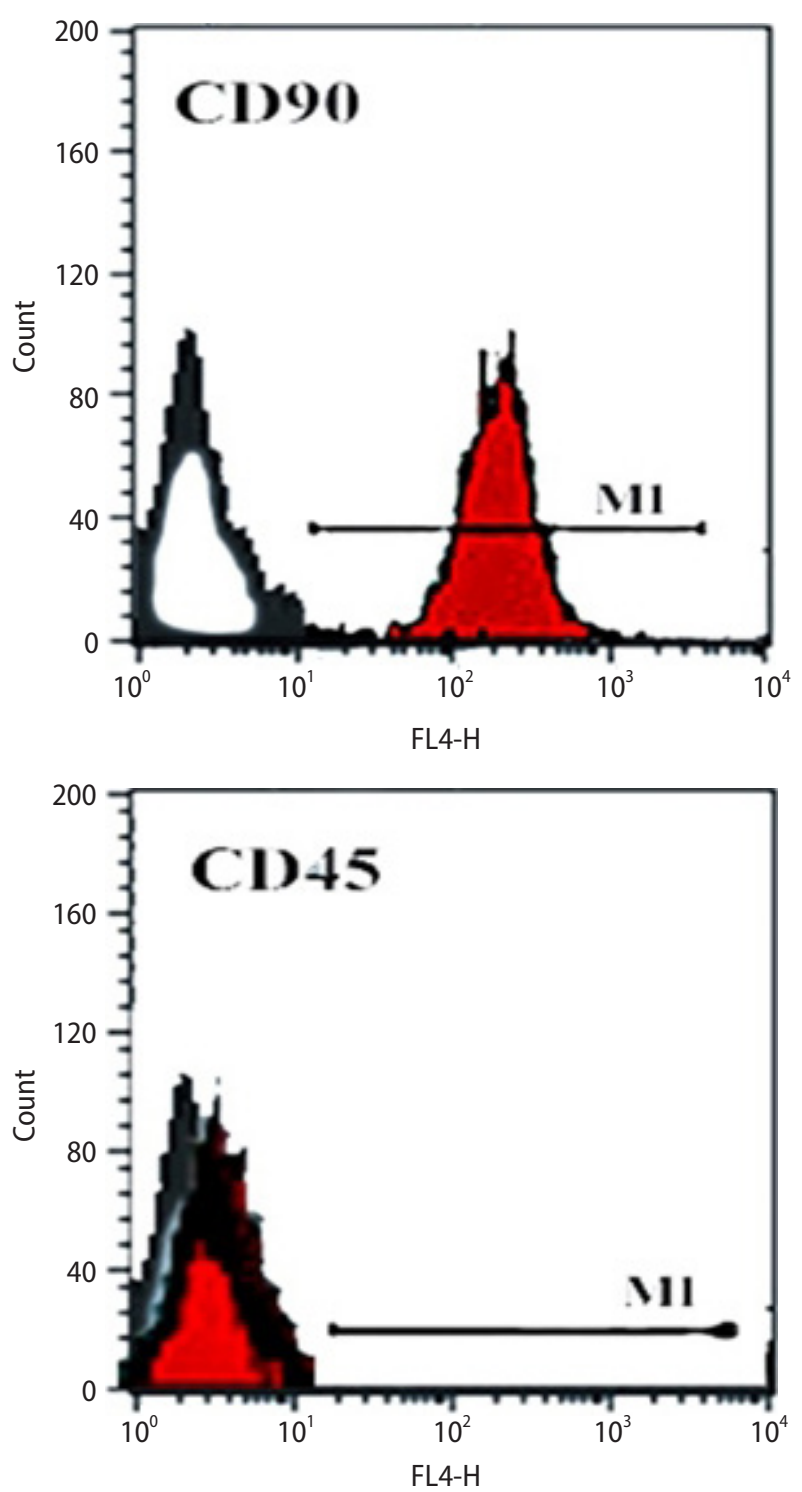

vealed strong nuclear expression of Ki67 in the epithelial lining of endometrial glands and stromal cells (Figure 5A and B). The stem cell treated group, on the other hand, had a slight positive response to Ki67 in endometrial stromal cells and a negative response in the epithelial lining of glands (Figure 5C-E). Enhanced expression of CD68 in the macrophages located around the endometrial glands was detected in the endometriosis group (Figure 6A). Higher magnification reveled strong CD68 positive cytoplasmic staining (Figure 6B). The expression, however, was hardly identified around the endometrial glands in the stem cell treated group (Figure 6C-E).

\section{Cytokine expression levels}

TNFa, IL6 and IL1 $\beta$ are pro-inflammatory, while INFy, TGF- $\beta$ and IL-
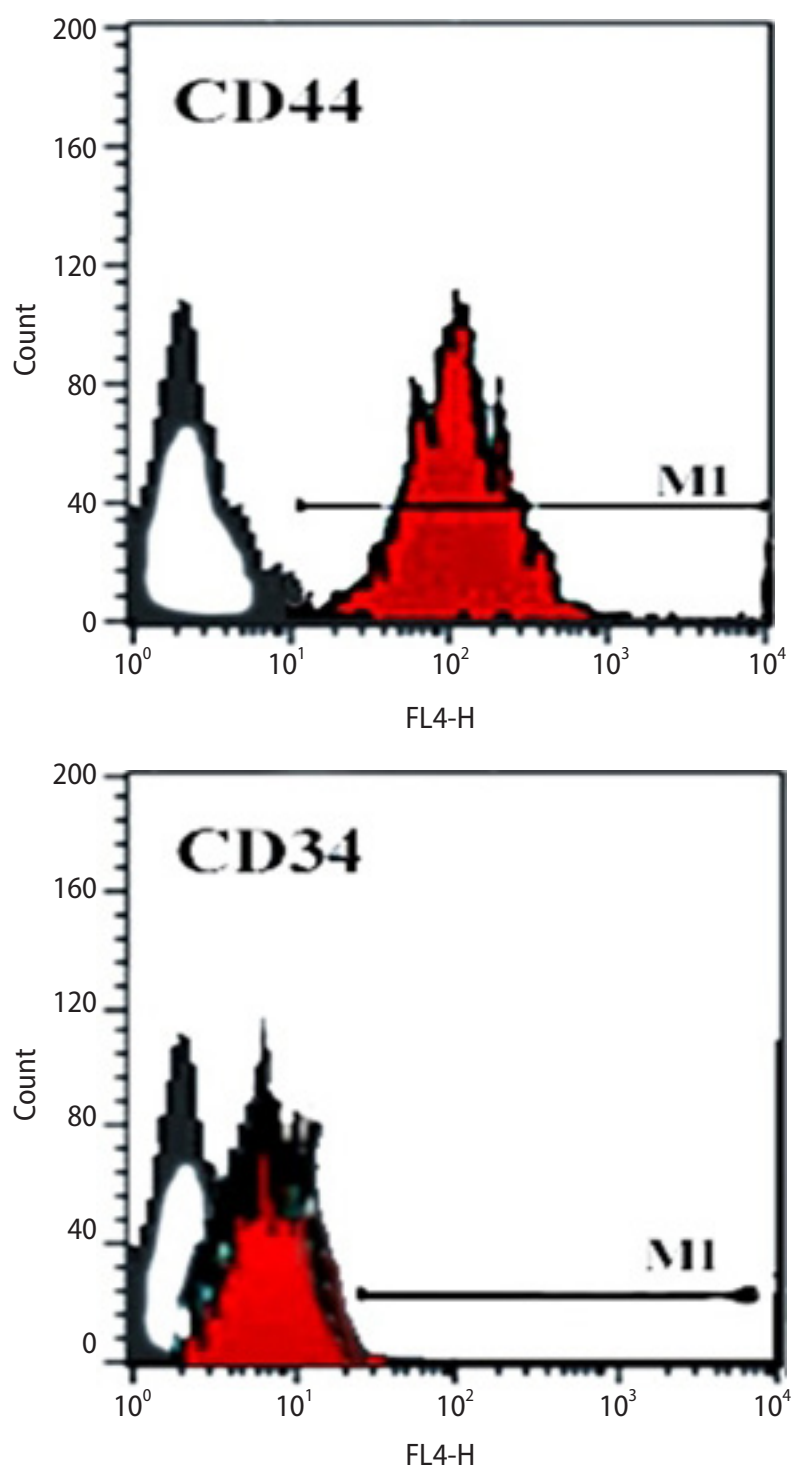

Figure 3. Expression of surface markers in adipose tissue-derived mesenchymal stem cells (fluorescence-activated cell sorting analysis). The cells showed positive expression of CD90 and CD44, and negative expression of CD45 and CD34. 

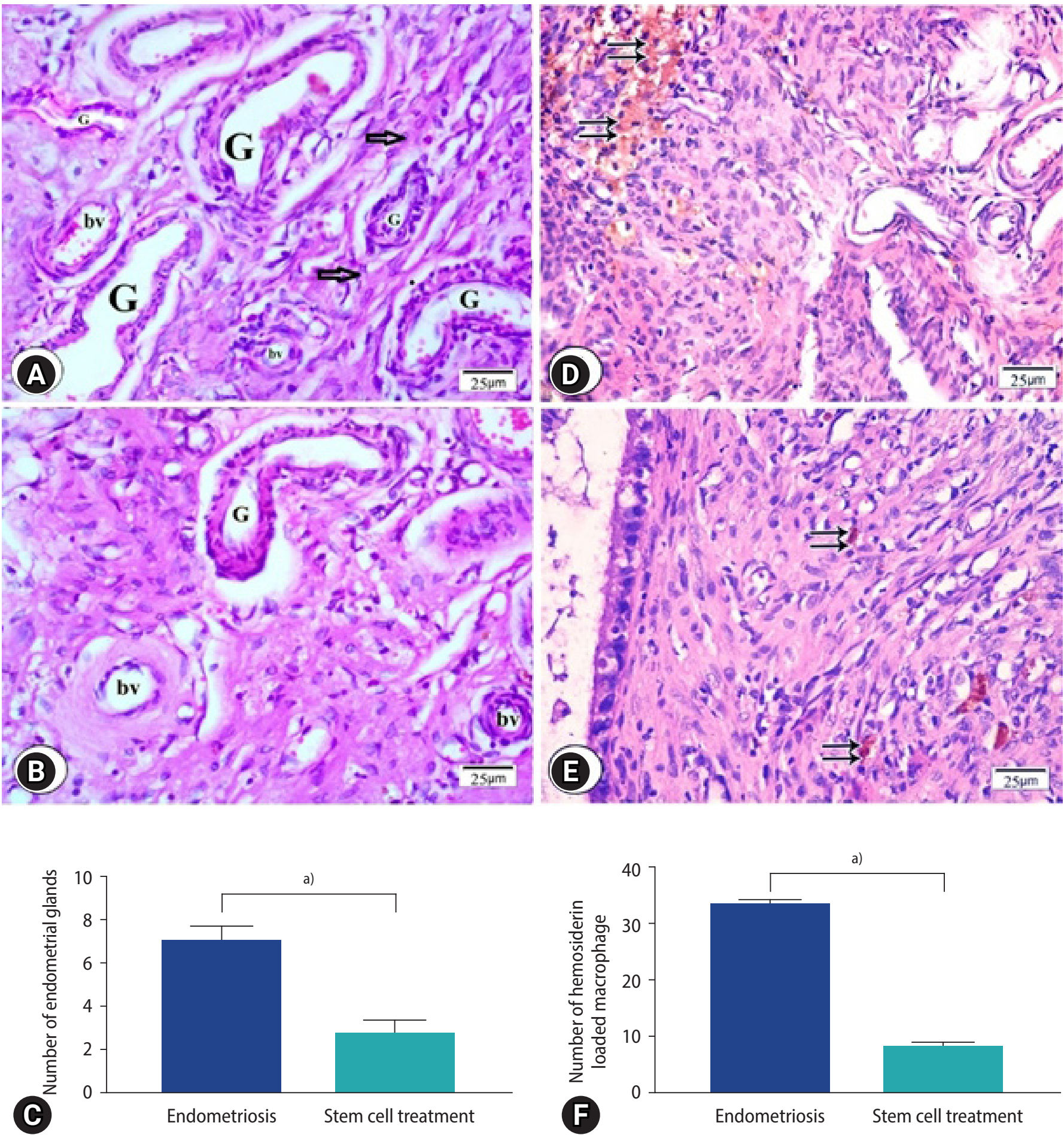

Figure 4. Photomicrographs of endometriosis lesions from the endometriosis group $(A, D)$ and the stem cell treated group $(B, E)$ stained by $H \& E$ showing $(A)$ multiple endometrial glands $(G)$, stromal cells (arrows) and multiple blood vessels (bv) in endometriosis group (B) few endometrial glands surrounded by blood vessels. (C) Number of endometrial glands. ${ }^{a} p<0.001$. (D) Endometriosis group; numerous hemosiderin-laden macrophages (double arrows), (E) stem cell treated group; few hemosiderin-laden macrophages were found (double arrows). (F) Number of hemosiderin loaded macrophage. (C, F) Values are presented as mean \pm standard error of the mean. ${ }^{a)} p<0.001$. 

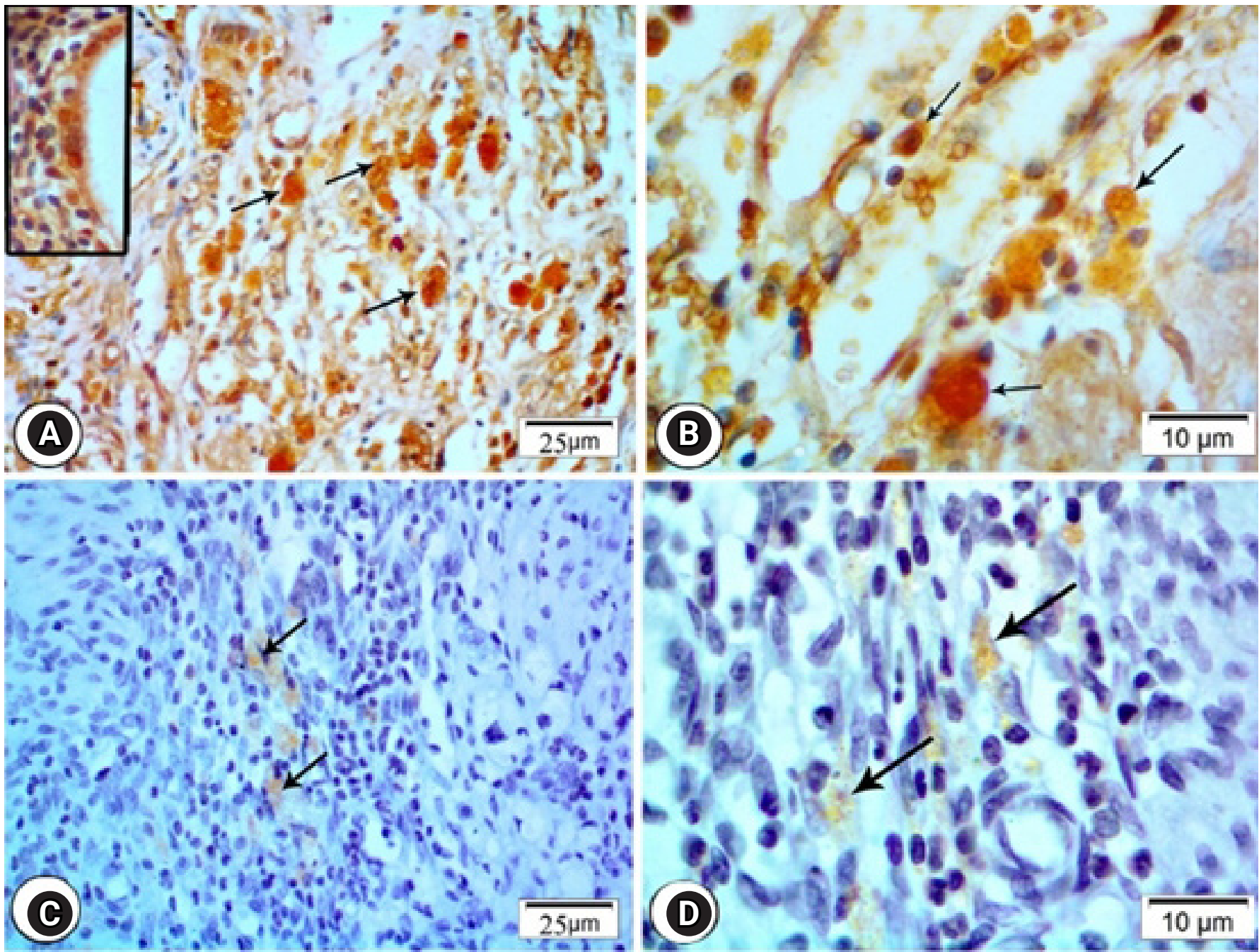

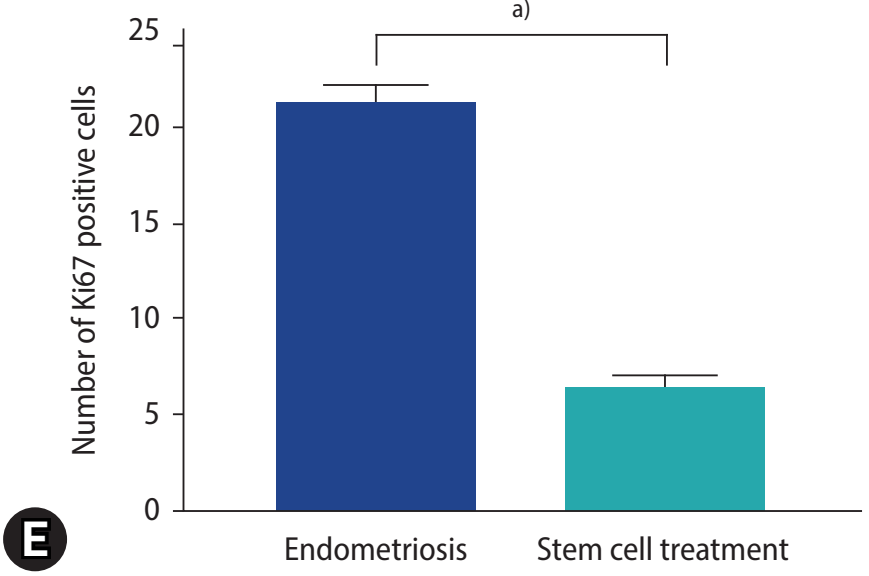

10 are immunomodulatory cytokines $[18,36]$. Rats treated with stem cells displayed lower expression levels of the proinflammatory and immunomodulatory cytokines, yet the later were less altered. IL-10 expression was significantly enhanced in stem cell treated group. Stem cell treatment induced marked reduction in IFNy expression in
Figure 5. Photomicrographs of ki67 immune expression in the endometriosis group (A) and the stem cell treated group (B). (A) Endometriosis group showing strong nuclear expression of Ki67 in the epithelial lining of endometrial glands (inset) and stromal cells (arrows; Ki67, $\times 400$ ). (B) Magnified photo showing the expression of the KI67 (arrows) in the cells in the endometriosis group (Ki67, $\times 1,000$ ). (C) Stem cell treated group showing mild immune expression in nuclei of stromal cells (arrows; Ki67, ×400). (D) Magnified photo showing the expression of the KI67 (arrows) in the cells in the stem cell treated group. (Ki67, X1,000). (E) Morphometric studies of ki67 expression. Values are presented as mean \pm standard error of the mean. ${ }^{\text {al }} p<0.001$.

both macrophages and endometriosis tissue (Figure 7) (mean fold change $=0.1 \pm 0.27$ and $0.4 \pm 0.11$ in macrophage and endometriosis tissue of stem cell treated group compared to the endometriosis group, respectively). Likewise, the expression of TNF- $a$ by the peritoneal macrophages isolated from the stem cell treated rats was de- 

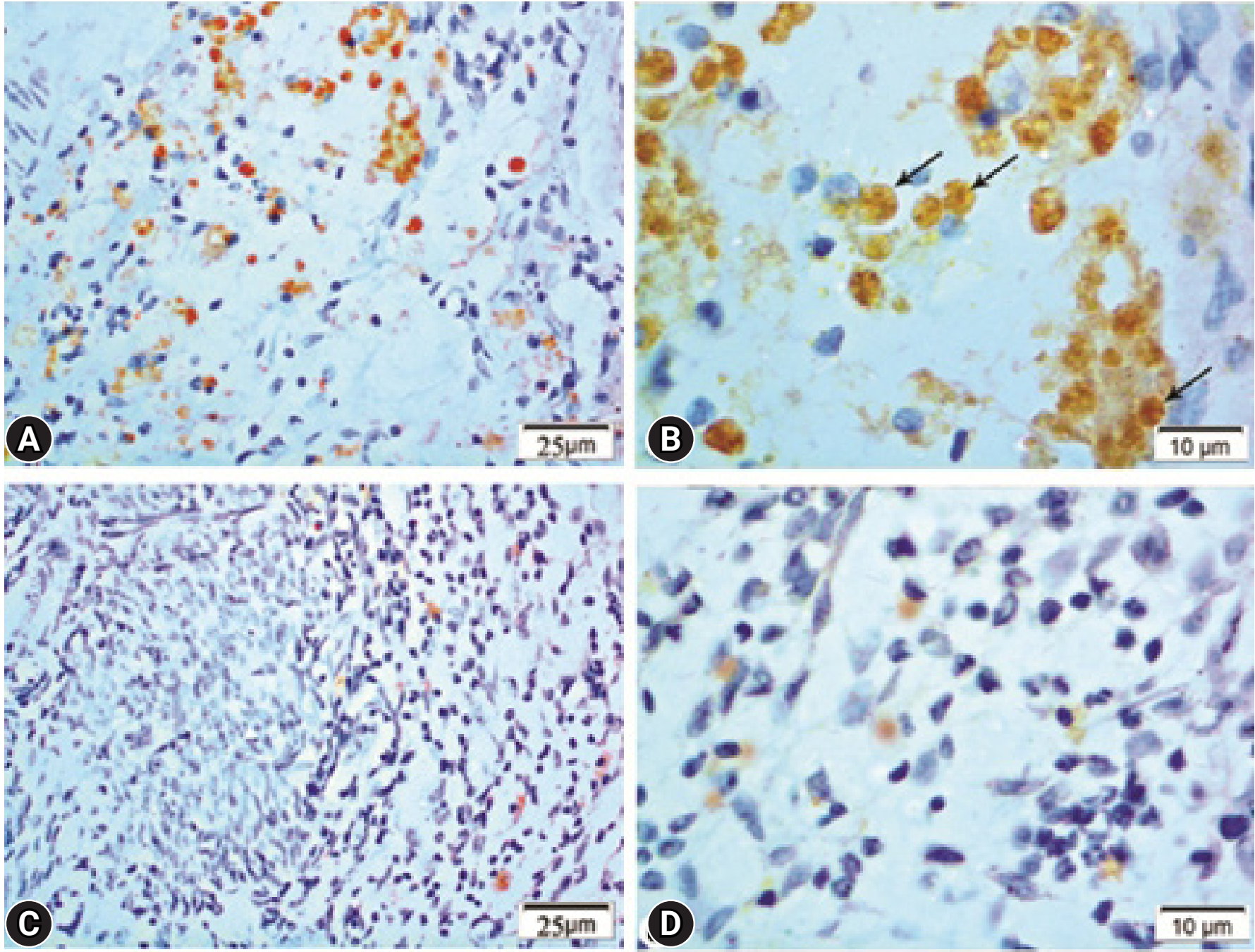

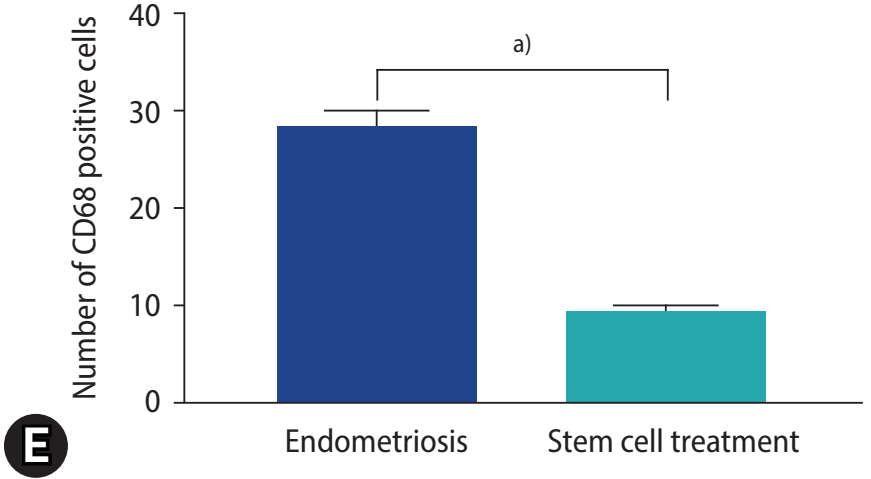

creased $(0.1 \pm 0.6, p=0.02)$ compared to those isolated from the endometriosis group. Lower level of TNF-a expression was observed in endometriosis tissue of the stem cell treated group $(0.4 \pm 0.2$, $p=0.03)$. Expression of IL- $1 \beta$ was lower $(0.5 \pm 0.2, p=0.04)$ in the endometriosis tissue of the stem cell treated group compared to the endometriosis group. IL-6 expression, on the other hand, was not
Figure 6. Photomicrographs showing immune expression of macrophage marker (CD68) in the endometriosis group (A, B) and the stem cell treated group (C, D). Endometriosis group showing (A) strong positive expression of CD68 in macrophage cells (CD68×400), (B) magnified part of the previous section showing positive expression in the form of brownish cytoplasmic granules (CD68, $\times 1,000$; arrows, CD68 expression). Stem cell treated group showing (C) weak expression of CD68 in macrophage cells (CD68×400), (D) magnified photo showing few numbers of CD68 immunopositive macrophages with pale stained cytoplasmic granules $(C D 68 \times 1,000)$. (E) Morphometric studies of CD68 expression. Values are presented as mean \pm standard error of the mean. ${ }^{\text {a) }} p<0.001$.

significantly altered in the stem cell treated group compared to the endometriosis group. The endometriosis tissue and the peritoneal macrophages were tested for the expression of the two anti-inflammatory cytokines; IL-10 and TGF- $\beta$. Interestingly, stem cell treated rats demonstrated two fold higher level of IL-10 $(2 \pm 0.3, p=0.01)$; however, TGF- $\beta$ has not been significantly altered in the endometriosis tis- 

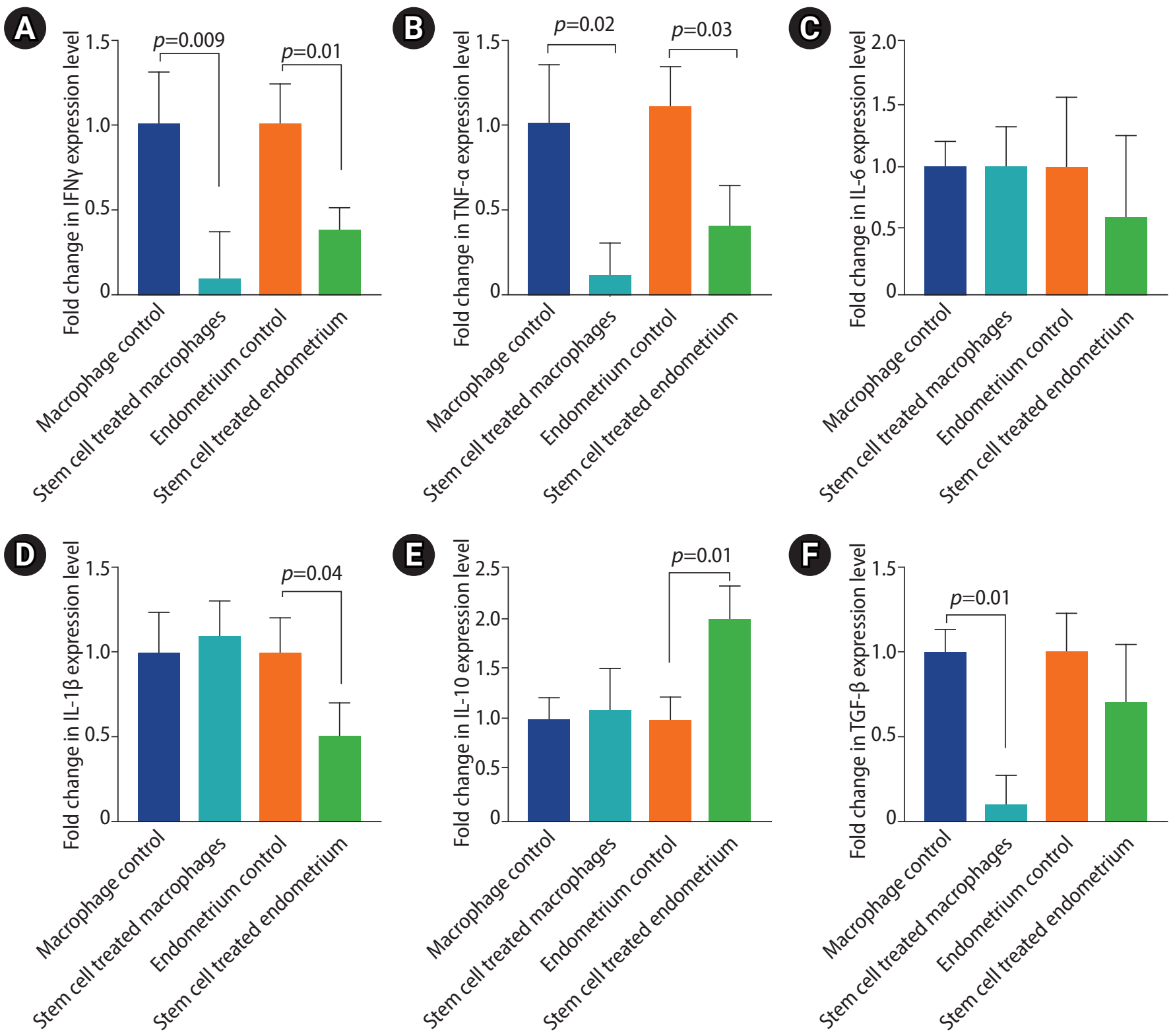

Figure 7. Cytokine expression levels in peritoneal macrophages and endometriosis tissues of the study groups. (A) Interferon (IFN)y. (B) Transforming growth factor (TNF)- $a$. (C) Interleukin (IL)-6. (D) IL-1 $\beta$. (E) IL-10. (F) Transforming growth factor (TGF)- $\beta$. Values are presented as mean \pm standard error of the mean. Macrophage control group is the peritoneal macrophage from endometriosis rats. Stem cell treated macrophage is the peritoneal macrophage from endometriotic rats but were treated by stem cells. Endometrial control is the macrophage from the endometriosis lesion and stem cell treated endometrium is the macrophage from endometriosis lesion in endometriotic rats treated by stem cells.

sue of either groups. IL-10 expression was not affected but TGF- $\beta$ was lower in the peritoneal macrophages of the stem cell treated group relative to the endometriosis group $(0.1 \pm 0.2, p=0.01)$.

\section{Discussion}

At the present study, we used an autologous endometriosis rat model without ovariectomy or any estradiol supplementation in or- der to mimic the human endometriosis. This model provides suitable and acceptable endometriosis lesions comparable with the moderate stage of human endometriosis. Our study revealed the mitigating effect of AD-MSCs on the endometriosis like lesions as evidenced by their antiproliferative and anti-inflammatory actions. AD-MSCs alleviated endometriosis associated chronic inflammatory reactions through decreased CD68 macrophage infiltration and some of the associated inflammatory cytokines expression. 
In our study, endometriosis group showed morphologically cystic implants consistent with other previous studies [37]. Experimental endometriosis detection was based on histopathologic observations of endometrial glands and stroma in the surgical site of endometrial square implantation. Light microscopy revealed ectopic endometrial glands and stroma, aggregating fibroblasts inside the peritoneum adjacent to uterine transplants, as well as mononuclear inflammatory cells and hemosiderin-laden macrophages, in accordance with previous studies [24]. Light and electron microscopic analysis of rat endometriosis demonstrated infiltration with eosinophils, mast cells, plasma cells, lymphocytes, and stromal macrophages of the peritoneum adjacent to implanted uterine tissue [38]. Uterine autotransplantation induced an immune reaction within the peritoneal stroma attached to the endometrial epithelium [38].

Previous theories explored the involvement of the immune system in promoting the development of endometriosis [39]. As macrophages liberating cytokines and growth factors at the site of endometriosis implants were studied to promote its growth [40], increasing evidence supports the concept of endometriosis as a pelvic inflammatory disorder [3]. Women with endometriosis have an increased fluid volume in the peritoneum, with an elevated concentration of activated macrophages, prostaglandins, cytokines or chemokines as macrophage migration inhibitory factor [41], TNF-a [42], IL$1 \beta$, IL-6 [43], IL-8 and monocyte chemoattractant protein-1 (MCP-1) [44]. IL-6 is one of the main mediators in the cytokine cascade of endometriosis and its elevated levels correlate with the disease activity [43]. TNF-a stimulates the expression of matrix metalloproteinase and inhibits their inhibitors' expression, hence contributing to the invasion of endometriosis and its extracellular matrix remodeling $[45,46]$. Both TNF- $a$ and IL- 8 concentrations in peritoneal fluid have been reported to correlate with the size and number of active endometriosis lesions [47]. Levels of proinflammatory cytokines IL-1, IL-6, TNF- $\alpha$, TGF- $\beta$, and vascular endothelial growth factor are synonymous with severity of endometriosis and presence of adhesion $[48,49]$. Furthermore, TGF- $\beta$ is a major driver of fibrosis in endometriosis [50]. As a result, targeting proinflammatory cytokines as a therapeutic strategy has been suggested. Because of its influence on dorsal root neurons, the pelvic inflammatory environment may contribute to the pathophysiology of pain perception $[3,51]$.

MSCs serve as an ideal candidate for cell-based therapies beside their immunosuppressive properties [52]. According to the Mesenchymal and Tissue Stem Cell Committee of the International Society for Cellular Therapy, the criteria to define MSCs include the expression of CD90, CD105, CD44, and CD73 and lack of expression of CD45, CD34, CD31, CD14 or CD11b, CD79a, and CD19 in addition to the ability to proliferate as plastic adherent cells in standard culture conditions and to differentiate into multiple cell lineages in vitro [53], which was well confirmed in our study.

MSCs have been suggested as a treatment modality for inflammatory [52] and autoimmune diseases as graft versus host disease, multiple sclerosis, and Crohn disease [54]. The anti-inflammatory role of MSCs became more apparent as the events initiating inflammation have been defined [55-58] due to their ability to sense the changing levels of inflammation in their microenvironment and respond accordingly [59]. Our study showed decreased the size of the endometriosis lesion as well as decreased number of endometrial glands which are consider as landmarks of endometriosis.

Decreased expression of IFN $\gamma$ and TNF- $a$ in the activated peritoneal macrophages and endometrium tissue of the stem cell treated group. Stem cell treatment induced enhanced expression of IL-10 in endometrial tissue and TGF- $\beta$ suppression in the activated macrophages of the peritoneum. MSCs are turned on by signals from injured tissues to secrete anti-inflammatory factors [60]. The production of proinflammatory cytokines by M1 macrophages or activated T cells may activate MSCs and stimulate release of mediators that distort the differentiation of monocytes toward an anti-inflammatory profile and eventually toward M2 macrophages [61]. M2 polarized macrophages generate IL-10 and facilitate the emergence of Tregs specialized in suppression of T cell-mediated immune responses [62] leading to amplification of the anti-inflammatory response [62]. In addition CCL18, a factor produced by M2 macrophages, promotes the generation of Tregs in conjunction with TGF- $\beta$ [63]. TNF- $a$ and other proinflammatory cytokines from resident macrophages activate MSCs to secrete the multifunctional anti-inflammatory protein; TNF-a-stimulated gene/protein 6 (TSG-6) [60]. The TSG-6 lowers nuclear factor- $\mathrm{kB}$ signaling in the resident macrophages modulating the cascade of proinflammatory cytokines [64]. Furthermore, TNF-a, nitric oxide, and probably other damage-associated molecular patterns from injured tissues and macrophages activate MSCs to secrete prostaglandin E2 [60] that converts macrophages to the M2 phenotype [60]. MSCs may produce anti-inflammatory effects by enhancing expression of the anti-reactive oxygen species protein stanniocalcin-1 as well [65].

Despite previous research suggesting that AD-MSCs may aid in the maintenance and growth of ectopic endometrial tissue [52], our results documented that AD-MSCs treated group showed smallsized endometrial glands surrounded by stromal cells with lesser inflammatory cellular infiltration compared to the endometriosis group. Our findings are consistent with the study that showed that transplanted menstrual blood MSCs improved fertility substantially by increasing the synthesis of angiogenic and anti-inflammatory factors [66]. Human endometrial MSCs were successfully applied for Asherman's syndrome treatment in the rat model indicated through the higher pregnancy outcome and litter size compared with those 
received autologous rat bone marrow cells [66].

Macrophages are the key cells contributing to the local inflammatory response in endometriosis [67]. Monocytes are recruited to the endometriosis lesion by the chemotactic chemokine MCP-1 then transformed into mature macrophages [67]. The hemosiderin loaded macrophage were significantly decreased via treatment with MSCs which was confirmed by immunohistochemical staining using CD68.

CD68 is a glycoprotein surface marker expressed on the circulating and tissue macrophages [68]. Our study showed high CD68 expression in ectopic endometrium in the endometriosis group however, very faint expression was observed around the endometrial glands in the stem cell treated group. There was a statistically significant difference between the values of CD68 for endometriosis of the ovaries, endometriosis of the pelvis, adenomyosis, endometriosis of the abdominal wall compared to normal endometrium [69]. The maximum frequency of endometriosis-associated immune cell infiltrates as macrophages (CD68+) was observed in peritoneal and ovarian endometriosis [70].

Ki67 represents a nuclear protein associated with cell division as it is present during all active phases of the cell cycle (G1, S, G2 and mitosis), however absent in G0. It represents a marker of cell proliferation [71]. In our study, many epithelial cells of endometriosis group showed Ki67 positive nuclear staining with immunoreactivity in some proportion of cells in the cytoplasm as well. Stem cell treated group showed mild positive reaction in endometrial stromal cells and negative reaction in the glands. Positivity of the Ki67 proliferation marker is directed toward increased aggressiveness of endometrial ectopic tissue being directly proportional to the size of endometriosis foci [69]. The expression of this marker is low in cases of moderate endometriosis and increased in severe ones [72]. Women aged 36-47 with regular menstrual cycle, demonstrated a significant increase of $\mathrm{Ki} 67 \mathrm{H}$ score in the stroma of eutopic endometrium of those affected by endometriosis suggesting an enhancement of the proliferative processes in this location [73].

MSCs could be efficiently used as an adjuvant therapy for mitigating the inflammatory component of endometriosis which consequently mediate the antiproliferative effect on endometriosis cells. Further studies are still required to enclose MSCs in a beneficial regimen that could alleviate endometriosis distressing manifestations keep fertility and decrease the incidence of recurrence.

\section{Conflict of interest}

No potential conflict of interest relevant to this article was reported.

\section{Acknowledgments}

We are grateful to Prof. Dina Sabry (Medical Biochemistry and Molecular Biology Department, Faculty of Medicine, Badr University in Cairo, Badr City, Egypt for) for her kind assistance in the experiments of characterization of the stem cells. We acknowledge the members of Reproductive Science Research Center, Assiut University, Assiut, Egypt for their valuable support.

\section{ORCID}

Lobna A. Abdelzaher

https://orcid.org/0000-0001-8438-7924

Essam R. Othman

https://orcid.org/0000-0002-5795-5831

\section{Author contributions}

Conceptualization: FYM, DAE, LAA, MAEM, AAS, AMR, ERO. Data curation: all authors. Formal analysis: FYM, DAE, LAA, MAEM, AAS, AMR, ERO. Funding acquisition: FYM, DAE, LAA, MAEM, AAS, AMR, ERO. Methodology: FYM, DAE, LAA, MAEM, AAS, AMR, ERO. Project administration: FYM, DAE, LAA, MAEM, AAS, AMR, ERO. Visualization: FYM, DAE, LAA, MAEM, AAS, AMR, ERO. Writing-original draft: LAA. Writing-review \& editing: all authors.

\section{References}

1. Lafay Pillet MC, Huchon C, Santulli P, Borghese B, Chapron C, Fauconnier A. A clinical score can predict associated deep infiltrating endometriosis before surgery for an endometrioma. Hum Reprod 2014;29:1666-76.

2. Nisolle M, Donnez J. Peritoneal endometriosis, ovarian endometriosis, and adenomyotic nodules of the rectovaginal septum are three different entities. Fertil Steril 1997;68:585-96.

3. Burney RO, Giudice LC. Pathogenesis and pathophysiology of endometriosis. Fertil Steril 2012;98:511-9.

4. Eskenazi B, Warner ML. Epidemiology of endometriosis. Obstet Gynecol Clin North Am 1997;24:235-58.

5. De Oliveira R, Musich DD, Ferreira MP, Vilarino FL, Barbosa CP. Epidemiological profile of infertile patients with endometriosis. Reprod Climaterio 2015;30:5-10.

6. Stratton P. The association of clinical symptoms with deep infiltrating endometriosis: the importance of the preoperative clinical assessment. Hum Reprod 2014;29:1627-8.

7. Simoens S, Dunselman G, Dirksen C, Hummelshoj L, Bokor A, Brandes I, et al. The burden of endometriosis: costs and quality of life of women with endometriosis and treated in referral centres. Hum Reprod 2012;27:1292-9. 
8. Ahn SH, Monsanto SP, Miller C, Singh SS, Thomas R, Tayade C. Pathophysiology and immune dysfunction in endometriosis. Biomed Res Int 2015;2015:795976.

9. Giudice LC, Kao LC. Endometriosis. Lancet 2004;364:1789-99.

10. Lousse JC, Van Langendonckt A, Defrere S, Ramos RG, Colette S, Donnez J. Peritoneal endometriosis is an inflammatory disease. Front Biosci (Elite Ed) 2012;4:23-40.

11. Tanbo T, Fedorcsak P. Endometriosis-associated infertility: aspects of pathophysiological mechanisms and treatment options. Acta Obstet Gynecol Scand 2017;96:659-67.

12. Hever A, Roth RB, Hevezi P, Marin ME, Acosta JA, Acosta $H$, et al. Human endometriosis is associated with plasma cells and overexpression of B lymphocyte stimulator. Proc Natl Acad Sci U S A 2007;104:12451-6.

13. Kyama CM, Debrock S, Mwenda JM, D'Hooghe TM. Potential involvement of the immune system in the development of endometriosis. Reprod Biol Endocrinol 2003;1:123.

14. Oosterlynck DJ, Cornillie FJ, Waer M, Koninckx PR. Immunohistochemical characterization of leucocyte subpopulations in endometriotic lesions. Arch Gynecol Obstet 1993;253:197-206.

15. Taylor RN, Ryan IP, Moore ES, Hornung D, Shifren JL, Tseng JF. Angiogenesis and macrophage activation in endometriosis. Ann NY Acad Sci 1997;828:194-207.

16. Taylor RN, Lebovic DI, Mueller MD. Angiogenic factors in endometriosis. Ann NY Acad Sci 2002;955:89-100.

17. Vinatier D, Dufour P, Oosterlynck D. Immunological aspects of endometriosis. Hum Reprod Update 1996;2:371-84.

18. Wu MY, Ho HN. The role of cytokines in endometriosis. Am J Reprod Immunol 2003;49:285-96.

19. Bacci M, Capobianco A, Monno A, Cottone L, Di Puppo F, Camisa B, et al. Macrophages are alternatively activated in patients with endometriosis and required for growth and vascularization of lesions in a mouse model of disease. Am J Pathol 2009;175:547-56.

20. Donnez J, Smoes P, Gillerot S, Casanas-Roux F, Nisolle M. Vascular endothelial growth factor (VEGF) in endometriosis. Hum Reprod 1998;13:1686-90.

21. Schor E, de Freitas V, Simoes JM, Baracat EC. Endometriose: modelo experimental em ratas. Rev Bras Ginecol Obstet 1999;21:28184.

22. Greaves E, Cousins FL, Murray A, Esnal-Zufiaurre A, Fassbender A, Horne AW, et al. A novel mouse model of endometriosis mimics human phenotype and reveals insights into the inflammatory contribution of shed endometrium. Am J Pathol 2014;184:1930-9.

23. Garai J, Molnar V, Varga T, Koppan M, Torok A, Bodis J. Endometriosis: harmful survival of an ectopic tissue. Front Biosci 2006;11: 595-619.

24. Elgamal DA, Othman ER, Ahmed SF. Ultrastructural features of eu- topic endometrium in a rat model of endometriosis. J Microsc Ultrastruct 2016;4:20-7.

25. Dhesi AS, Morelli SS. Endometriosis: a role for stem cells. Womens Health (Lond) 2015;11:35-49.

26. Mundra V, Gerling IC, Mahato RI. Mesenchymal stem cell-based therapy. Mol Pharm 2013;10:77-89.

27. Doorn J, Moll G, Le Blanc K, van Blitterswijk C, de Boer J. Therapeutic applications of mesenchymal stromal cells: paracrine effects and potential improvements. Tissue Eng Part B Rev 2012;18:10115.

28. Silva JC, Silva AC, Reis FJ, Garcia SB, Sa MF, Nogueira AA. Development of an experimental model of endometriosis in rabbits. Int Congr Ser 2004;1271:248-51.

29. Vernon MW, Wilson EA. Studies on the surgical induction of endometriosis in the rat. Fertil Steril 1985;44:684-94.

30. Berkley KJ, Cason A, Jacobs H, Bradshaw H, Wood E. Vaginal hyperalgesia in a rat model of endometriosis. Neurosci Lett 2001; 306:185-8.

31. Tirado-González I, Barrientos G, Tariverdian N, Arck PC, García MG, Klapp BF, et al. Endometriosis research: animal models for the study of a complex disease. J Reprod Immunol 2010;86:141-7.

32. Mailey B, Hosseini A, Baker J, Young A, Alfonso Z, Hicok K, et al. Adipose-derived stem cells: methods for isolation and applications for clinical use. Methods Mol Biol 2014;1210:161-81.

33. Meligy FY, Shigemura K, Behnsawy HM, Fujisawa M, Kawabata M, Shirakawa T. The efficiency of in vitro isolation and myogenic differentiation of MSCs derived from adipose connective tissue, bone marrow, and skeletal muscle tissue. In Vitro Cell Dev Biol Anim 2012;48:203-15.

34. Bancroft JD, Gamble M. Theory and practice of histological techniques. 6th ed. Edinburgh: Churchill Livingstone; 2008.

35. El-Mokhtar MA, Bauer A, Madela J, Voigt S. Cellular distribution of CD200 receptor in rats and its interaction with cytomegalovirus e127 protein. Med Microbiol Immunol 2018;207:307-18.

36. OuYang Z, Hirota Y, Osuga Y, Hamasaki K, Hasegawa A, Tajima T, et al. Interleukin-4 stimulates proliferation of endometriotic stromal cells. Am J Pathol 2008;173:463-9.

37. Güney M, Oral B, Karahan N, Mungan T. Regression of endometrial explants in a rat model of endometriosis treated with melatonin. Fertil Steril 2008;89:934-42.

38. Uchiide I, Ihara T, Sugamata M. Pathological evaluation of the rat endometriosis model. Fertil Steril 2002;78:782-6.

39. Figueira PG, Abrão MS, Krikun G, Taylor HS. Stem cells in endometrium and their role in the pathogenesis of endometriosis. Ann $\mathrm{N}$ Y Acad Sci 2011;1221:10-7.

40. Olive DL, Weinberg JB, Haney AF. Peritoneal macrophages and infertility: the association between cell number and pelvic patholo- 
gy. Fertil Steril 1985;44:772-7.

41. Kats R, Collette T, Metz CN, Akoum A. Marked elevation of macrophage migration inhibitory factor in the peritoneal fluid of women with endometriosis. Fertil Steril 2002;78:69-76.

42. Eisermann J, Gast MJ, Pineda J, Odem RR, Collins JL. Tumor necrosis factor in peritoneal fluid of women undergoing laparoscopic surgery. Fertil Steril 1988;50:573-9.

43. Harada T, Yoshioka H, Yoshida S, Iwabe T, Onohara Y, Tanikawa M, et al. Increased interleukin-6 levels in peritoneal fluid of infertile patients with active endometriosis. Am J Obstet Gynecol 1997; 176:593-7.

44. Akoum A, Metz CN, Al-Akoum M, Kats R. Macrophage migration inhibitory factor expression in the intrauterine endometrium of women with endometriosis varies with disease stage, infertility status, and pelvic pain. Fertil Steril 2006;85:1379-85.

45. Osteen KG, Bruner-Tran KL, Ong D, Eisenberg E. Paracrine mediators of endometrial matrix metalloproteinase expression: potential targets for progestin-based treatment of endometriosis. Ann NY Acad Sci 2002;955:139-46.

46. Sillem M, Prifti S, Koch A, Neher M, Jauckus J, Runnebaum B. Regulation of matrix metalloproteinases and their inhibitors in uterine endometrial cells of patients with and without endometriosis. Eur J Obstet Gynecol Reprod Biol 2001;95:167-74.

47. Harada T, Enatsu A, Mitsunari M, Nagano Y, Ito M, Tsudo T, et al. Role of cytokines in progression of endometriosis. Gynecol Obstet Invest 1999;47 Suppl 1:34-9.

48. Barcz E, Milewski L, Dziunycz P, Kaminski P, Ploski R, Malejczyk J. Peritoneal cytokines and adhesion formation in endometriosis: an inverse association with vascular endothelial growth factor concentration. Fertil Steril 2012;97:1380-6.e1.

49. Cheong YC, Shelton JB, Laird SM, Richmond M, Kudesia G, Li TC, et al. IL-1, IL-6 and TNF-alpha concentrations in the peritoneal fluid of women with pelvic adhesions. Hum Reprod 2002;17:69-75.

50. Vigano P, Candiani M, Monno A, Giacomini E, Vercellini P, Somigliana $\mathrm{E}$. Time to redefine endometriosis including its pro-fibrotic nature. Hum Reprod 2018;33:347-52.

51. Asante A, Taylor RN. Endometriosis: the role of neuroangiogenesis. Annu Rev Physiol 2011;73:163-82.

52. Abomaray F, Gidlof S, Bezubik B, Engman M, Gotherstrom C. Mesenchymal stromal cells support endometriotic stromal cells in vitro. Stem Cells Int 2018;2018:7318513.

53. Dominici M, Le Blanc K, Mueller I, Slaper-Cortenbach I, Marini F, Krause D, et al. Minimal criteria for defining multipotent mesenchymal stromal cells: the International Society for Cellular Therapy position statement. Cytotherapy 2006;8:315-7.

54. Squillaro T, Peluso G, Galderisi U. Clinical trials with mesenchymal stem cells: an update. Cell Transplant 2016;25:829-48.
55. Chen GY, Nunez G. Sterile inflammation: sensing and reacting to damage. Nat Rev Immunol 2010;10:826-37.

56. Eigenbrod T, Park JH, Harder J, Iwakura Y, Nunez G. Cutting edge: critical role for mesothelial cells in necrosis-induced inflammation through the recognition of IL-1 alpha released from dying cells. J Immunol 2008;181:8194-8.

57. Rock KL, Latz E, Ontiveros F, Kono H. The sterile inflammatory response. Annu Rev Immunol 2010;28:321-42.

58. Soehnlein O, Lindbom L. Phagocyte partnership during the onset and resolution of inflammation. Nat Rev Immunol 2010;10:42739.

59. Dorronsoro A, Fernandez-Rueda J, Fechter K, Ferrin I, Salcedo JM, Jakobsson $\mathrm{E}$, et al. Human mesenchymal stromal cell-mediated immunoregulation: mechanisms of action and clinical applications. Bone Marrow Res 2013;2013:203643.

60. Prockop DJ, Oh JY. Mesenchymal stem/stromal cells (MSCs): role as guardians of inflammation. Mol Ther 2012;20:14-20.

61. Le Blanc K, Mougiakakos D. Multipotent mesenchymal stromal cells and the innate immune system. Nat Rev Immunol 2012;12: 383-96.

62. Bernardo ME, Fibbe WE. Mesenchymal stromal cells: sensors and switchers of inflammation. Cell Stem Cell 2013;13:392-402.

63. Melief SM, Schrama E, Brugman MH, Tiemessen MM, Hoogduijn MJ, Fibbe WE, et al. Multipotent stromal cells induce human regulatory $T$ cells through a novel pathway involving skewing of monocytes toward anti-inflammatory macrophages. Stem Cells 2013;31:1980-91.

64. Oh JY, Roddy GW, Choi H, Lee RH, Ylostalo JH, Rosa RH Jr, et al. Anti-inflammatory protein TSG-6 reduces inflammatory damage to the cornea following chemical and mechanical injury. Proc Natl Acad Sci U S A 2010;107:16875-80.

65. Wang Y, Huang L, Abdelrahim M, Cai Q, Truong A, Bick R, et al. Stanniocalcin-1 suppresses superoxide generation in macrophages through induction of mitochondrial UCP2. J Leukoc Biol 2009;86:981-8.

66. Domnina A, Novikova P, Obidina J, Fridlyanskaya I, Alekseenko L, Kozhukharova I, et al. Human mesenchymal stem cells in spheroids improve fertility in model animals with damaged endometrium. Stem Cell Res Ther 2018;9:50.

67. Waiyaput W, Pumipichet S, Weerakiet S, Rattanasiri S, Sophonsritsuk $A$. Effect of simvastatin on monocyte chemoattractant protein-1 expression in endometriosis patients: a randomized controlled trial. BMC Womens Health 2017; 17:89.

68. Holness CL, Simmons DL. Molecular cloning of CD68, a human macrophage marker related to lysosomal glycoproteins. Blood 1993;81:1607-13.

69. Istrate-Ofiteru AM, Pirici D, Niculescu M, Berceanu C, Berceanu S, 
Voicu NL, et al. Clinical, morphological and immunohistochemical survey in different types of endometriosis. Rom J Morphol Embryol 2018;59:1133-53.

70. Scheerer C, Bauer P, Chiantera V, Sehouli J, Kaufmann A, Mechsner S. Characterization of endometriosis-associated immune cell infiltrates (EMalCI). Arch Gynecol Obstet 2016;294:657-64.

71. Scholzen T, Gerdes J. The Ki-67 protein: from the known and the unknown. J Cell Physiol 2000;182:311-22.

72. Bratila E, Bratila CP, Comandasu DE, Bausic V, Vladescu CT, Mehed- intu C, et al. The assessment of immunohistochemical profile of endometriosis implants, a practical method to appreciate the aggressiveness and recurrence risk of endometriosis. Rom J Morphol Embryol 2015;56:1301-7.

73. Goteri G, Altobelli E, Tossetta G, Zizzi A, Avellini C, Licini C, et al. High temperature requirement $A 1$, transforming growth factor beta1, phosphoSmad2 and Ki67 in eutopic and ectopic endometrium of women with endometriosis. Eur J Histochem 2015;59: 2570. 